\title{
Awareness Level of Professional Independence Requirements, through Assimilation of Fundamental Principles of Professional Ethics, by Jordanian CPA Auditors, in Auditing Process: Field Study
}

\author{
Raed Jameel Jaber ${ }^{1}$ \& Marwan Mohammad Abu Fadda ${ }^{2}$ \\ ${ }^{1}$ Accounting Department, Zarqa University, Jordan \\ ${ }^{2}$ Researcher at the Ministry of Finance, Palestine State \\ Correspondence: Raed Jameel Jaber, Assistant Professor, Accounting Department, Zarqa University, P.O. Box: \\ 132222, Zarqa 13132, Jordan. Tel: 962-790-289-352. E-mail: rjaber@zu.edu.jo
}

Received: June 18, 2016

Accepted: August 5, 2016

Online Published: August 25, 2016

doi:10.5539/ijef.v8n9p11

URL: http://dx.doi.org/10.5539/ijef.v8n9p11

\begin{abstract}
This research paper aimed at determining Awareness Level of Professional Independence Requirements (ALOPIR), through assimilation of fundamental principles of professional ethics, by Jordanian CPA auditors, in auditing process. A questionnaire was established and developed for this purpose and given out to external Jordanian audit firms and CPA auditors, the number of questionnaires which were exposed to analysis was (40), extracted data was analyzed using (SPSS), and a number of statistical tests; was achieved.

The study found positive correlation relationships between the stated variables; (high positive correlation between "professional competence and due care, professional behavior, safeguards threats"; moderate positive correlation between "objectivity, confidentiality"; low positive correlation between "integrity" and (ALOPIR)),

Despite the fact that the results indicate to the existence of certain (ALOPIR) by Jordanian CPA auditors; yet the low and moderate correlation of some variables may emerge a sign that the auditors awareness of some independence concepts is still below the demanded level; as the correlation was low with integrity and moderate with objectivity and confidentiality, such a matter must be paid more attention. The low positive correlation between integrity and (ALOPIR) can be explained by the probable that auditors may predominant their financial interests than to achieve integrity and honesty; this may be due to the absence of a declared Ethics Charter of audit in Jordan.

A standardized mean test was done to accept or reject either the null hypothesis or the alternative hypothesis, according to a comparison between each of the variables' joint mean and the standardized one, following that it was possible to descending sorting of the hypotheses depending on the joint mean value.

A main recommendation was introduced which is: to take steps to achieve imminent, deep and effectively spreading of relative culture, especially the fundamental principles of professional ethics, among professional accountants.
\end{abstract}

Keywords: professional independence, integrity, objectivity, professional competence and due care, professional behavior, confidentiality, safeguards, threats

\section{Introduction}

A distinctive indication of the accountancy profession is it's agreeable of the responsibility to act in the public interest. Consequently, a professional accountant's responsibility is not solely to satisfy the needs of an individual client or employer. In acting in the public interest, a professional accountant shall keep an eye on and comply with the "Code of Ethics for Professional Accountants" (International Ethics Standards, Board for Accountants-IESBA, 2013, p. 11).

The subject of the auditor independence is generally considered one of the important issues, which was - and still - plays an important role in achieving the objectives of the audit process. As many of the researchers noted in their studies that; the auditor independence is considered to be the cornerstone in the auditing profession, alongside with auditor's work with integrity and impartiality, whereas integrity is the fundamental guarantee for the issuance of a report form, expressing the fairness of financial statements, and free of material deviations. 


\section{But, what is the content of professional independence concept?}

Independence is both: (a) Independence of mind: the state of mind that allows the expression of a consequence without being affected by influences that adjust professional judgment, in addition to; (b) Independence in appearance: the averting of facts and circumstances that are so significant that a rational and informed third party would be likely to deduce, weighing all the specific facts and state of affairs (IESBA, 2013, 147-148). So; any pressure might be exposed to the external auditor of the enterprise manager or any party, is considered to be a clearly and an explicitly a threat to the auditor independence.

Here; the phrase "auditor independence" is intended to mean: "professional independence" hauled; independence in Figure (physical independence), and independence in content (actual) autonomy.

In the real and practical environment; the professional accountants suffer from the absence of a declared Ethics Charter of audit in Jordan, besides what is available is informal project of professional behavior rules, which was made 15 years ago.

In 2000, The Professional Behavior Committee of the Chartered Accountants Society in Jordan-SJCAs, prepared a project of professional behavior rules, these rules were initially confirmed starting from 5/7/2000 (Karaja, 2004). Since that date; the Chartered Accountants Society Board did not take any serious resumption to apply, or to generalize or to publicize these rules to professional accountants in an obligatory form.

The project contained a collection of principles and rules. The principles cover six main elements: 1- the auditor professional responsibility, 2- the public interest, 3- integrity, honesty and confidentiality, 4- objectivity and independence, 5- professional competence and due care, 6- the range and nature of services and professional behavior. The rules composed of (17) terms; the first was independence and dedication, the second was integrity and honesty (SJCAs, 2000). Here; the problem is: although these principles and rules took a great care regarding the professional accountant independence, it seems - through actual practices and conflicts of Jordanian professional accountants - that these principles and rules are not sufficiently applied.

On the other hand, the instructions published by Jordanian Securities Society (JSS) in 2014, regarding the external auditor stipulate on the approval of International Audit Standards issued by International Federation of Accountants, for the purpose of auditing the accounts of controlled organizations by (JSS), including the professional behavior rules issued by (IFAC). Whereas the US auditing standards were considered the principle of independence as a general criteria, that must be available to the auditor at all stages of the audit process.

The external auditor must carried out the auditing process, with integrity, impartiality and independence, and without being subject to any pressure or negative effects, whether they are linked to financial or other interests, the practical and appropriate environment must be available to the auditor, to achieve the material and actual independence requirements.

\section{The Problem Statement}

Awareness is known as the basic cognitive process for organizing information that comes to mind from the external environment at a given time. In other words; it is receiving, organizing, interpreting and translating the input received by the individual from the surrounding environment, where comparisons and the interaction are done between what is given of information or data, and their stored counterparts in the memory, in a manner that leads to a specific behavior. Also, it is the way in which the individual sees the world around him; this is done by receiving, organizing and interpreting information, and forming particular concepts and meanings.

On the other hand; "Professional" independence is a collection of characteristic actions resulting from the duty of care that emerged from the social contract with the public who has awarded the profession exclusive rights of title and/or practice in return for the commitment of self-regulation (Professional Independence, 2000).

Since the achievement of professional independence includes a deep understanding and conscious application of the independence components, and correct perception of its two parts represented in mental and phenotypic independence, or actual and physical independence, in addition to the full awareness of the threats that pose a real risk to the professional independence, and safeguards that prevent the effects of various threats, if they were possessed and implemented to the fullest, this study was to detect the level of awareness and understanding among those who engage in the auditing profession in Jordan.

\section{Rationale of the Study}

Knowledge is an ultimate strength. It is a lethal and a decisive weapon. It is a true, a straight and a right way in the face of threats, risks and unknowns whatever they varied or multituded. It is a powerful lever to seize positive opportunities and favorable conditions; it gives the power to neutralize negatives, evils and weaknesses 
to the point to overcome them and to be defeated. Also; it works to reinforce the positives and strengths, and to maximize the benefits and interests.

But the mere knowledge may not achieve the maximum benefit from owning the correct, appropriate and timely information; knowledge must be accompanied by the right ability to sense, simultaneous attention and exact interpretation to the event.

In this study, there are requirements, conditions, elements, environmental factors, physical procedures and ethical laws influence the level of professional independence of the auditor. The existence of these elements is very important in itself, but the most important is; the level of realization, awareness and understanding of the auditor to the essence and nature of these elements.

The higher the perception level arises, the higher the achievement level of professional independence in the audit process climbs. This is the logic upon which this study is based, which seeks to make sure of it, according to the scientific basis for scientific research.

\section{Objectives and Justifications}

This study aims to recognize the awareness, perception and understanding availability extent of the "Professional Independence" principle, which is necessary to the external Jordanian CPA. Also, to know their absorption extent of the requirements to achieve the "actual" and "material" independence, at every stage of audit process, especially the reporting stage, where the auditor must be fully aware of all of the:

- Concept of independence with its two composites,

- Fundamental principles of professional ethics through which the assimilation must be done,

- Requirements to achieve independence based on each of:

$\checkmark$ International Auditing Standards, rules of ethics of the accounting profession issued by the International Federation of Accountants,

$\checkmark$ Laws regulating the auditing profession in Jordan, and rules of professional conduct issued by the Accountants Association in Jordan.

- Safeguard components such as; various qualifications, relative training, governance elements, organizational procedures, local audit standards and international codes.

- Factors and causes that may pose a threat to the independence of the external auditor in Jordan.

\section{The Importance of the Study}

Numerous studies and research papers discussed the subject of professional independence of the external auditor, and its relationship with many subjects, such as the credibility of the audited and published data, the auditor performance and neutrality, the quality of audit processes, the impact of non-audit services on the auditor independence, the audit fees, regulatory reforms and legal systems, etc.

However, none of them did address or study some of the mental capabilities of the auditor, such as perception and understanding the regulatory and ethical requirements necessary to achieve the professional independence. From this point stems the study importance, in response to this subject through the study of the relationship between the awareness level, and the level of achieving the professional independence; through assimilation of fundamental principles of professional ethics, is it strong, positive and solid or otherwise?

\section{Benefits This Study May Deliver}

This study; through its findings and recommendations, may serve many related stakeholders to auditing profession in Jordan, that are concerned, attentive and interested in more availability, neutrality, independence and impartiality in the work of the auditor, whether these were governmental, or professional, or research entities.

As this study will show through the applied side the level of external auditors awareness and understanding in Jordan, to the principle of "professional independence" in the audit process, in the event if there is a weakness in their awareness of the independence requirements, or of the constraints that may affect them negatively.

\section{Literature Review \& Hypotheses}

This paper will discuss the key factors upon which this research was built, so as to reach the ultimate goal that involved in the main topic, as follows: 


\subsection{Awareness}

It is the ability to perceive, to feel, or to be conscious of events, objects, thoughts, emotions, or sensory patterns (http://www.merriam-webster.com/dictionary/awareness) in such level of recognition, sense data can be assured by a watcher without necessarily embodiment realization.

The maintenance of professional competence necessitates a perpetuate awareness and an understanding of pertinent technical, professional and business outgrowths (Charted Institute of Management Accountants CIMA, 2015, p. 14). In theory, auditors are definitely aware of their obligations and the objective of audit work (Barabás, 2013), whereas; the association between moral reasoning and auditor independence was examined because independence is grounded in an auditor's ethical reasoning ability (Hung-Chao, 2011).

It is impossible to enumerate all circumstances in which the appearance of independence might be questioned. Members should "be" aware of all the relevant facts; to conclude that there is an inadmissible threat to the member's and the firm's independence (AICPA Professional Ethics Executive Committee, 2001).

\subsection{Independence}

What does independence mean? With reference to the definition of the US Securities and Exchange Commission (SEC), independence is a mental state of impartiality and scarcity of bias (Rule 57; SEC, 2003) (Barabás, 2013).

It means being objective and free from bias or preconception .., (and) is governed by authoritative standard setters (BLANN, 2010). It is freedom from conditions and relationships which make it tolerable that a reasonable and informed third party would derive that objectivity either is impaired or could be impaired (The Auditing Practices Board, APB Ethical Standard 1 (revised), p. 6).

"Professional" independence is a set of discriminatory actions resulting from the duty of care that arises out of the social contract ... based on trust and confidence (Professional Independence and the ABCPF Member, 2000). Also it includes the qualities of integrity, objectivity and impartiality (Muthui et al., 2014).

Independence in fact attributes to the authentic objective state of the connection between medium auditing firms and their clients. Independence in appearance points out to the subjective state of that rapport as grasped by clients and third parties (Arens, Elder, \& Beasly, 2006).

Auditor independence is desirable because it is an input to reliable financial statements. It is not, however, an objective in and of itself (Ryan et al., 2001, pp. 373-386). It is the cornerstone of the accounting profession and one of its most priceless properties (Marshall, Geiger, Jordan, \& Kurt, 1999). So; maintaining auditor independence is vital to the auditing profession (Anil \& Jonathan, 2014).

The importance of auditor independence, both actual and as comprehend by others, has been excessively recognized both in theory and by regulators (Marshall, Geiger, Jordan, \& Kurt, 1999). The topic of auditor independence was extended to include the auditor decision process (Blay, 2005).

Independence can be thought of as a characterization of the auditor's attitude (Dopuch \& King, 1996; Darius \& Fatemi, 2012), influenced by the stage of ethical evolution, and the interaction between moral logic and justice beliefs (Hung-Chao, 2011), it plays a fundamental part in the goodness of auditing (Official Journal of the European Union, 2011).

It must be ensured that auditor independence requirements remain relevant, effective, and fair (Securities And Exchange Commission (SEC), Final Rule: 2001), but multiperiod nature of the auditor-client linkage, connected with cost advantages, gives incumbent auditors an impetus to compromise their independence in order to hold clients (Paterson, Jeffrey, \& Adrian, 2011).

The issue at the pulp of auditor independence argumentation is the anxiety that the auditor may defend for management, rather than view the investing public as the client (Barrett, Cooper, \& Jamal. 2005), and, It was found that transferring the hiring power from managers to investors enhances auditor independence (Mayhew, \& Pike, 2004).

\subsection{Integrity}

Integrity is to be; unpretentious and sincere in all professional and business relationships (CIMA, 2015, p. 9). Integrity also glimpses fair dealing and truthfulness (IESBA, 2013, p. 17). It is a prerequisite for all those who act in the public interest (The Auditing Practices Board, APB Ethical Standard 1 (revised), p. 4).

The auditor's independence consolidates the auditor's ability to act with integrity, be objective and maintain a position of professional scepticism (Professional Skepticism in an Audit of Financial Statements). Objectivity and professional integrity should be the domination principles underlying a legitimate auditor's audit opinion on 
financial statements (The Commission of the European Communities, no date).

Financial markets depend on the skillfulness and integrity of independent auditors to secure this quality and restatements are commonly associated with audit failures (Paterson, Jeffrey, \& Adrian, 2011). The audit firm shall estimate the threats to the auditor's objectivity and independence and shall stratify safeguards to decrease the threats to an agreeable level (APB Ethical Standard 3 (revised) Long Association with the Audit Engagement, 2009).

\subsection{Objectivity}

It is a state of mind, a quality that provides value to the member's services. It is a distinctive feature of the profession.., it imposes the commitment to be impartial and intellectually honest (Professional Independence and the ABCPF Member, May 2000).

It is; to not allow bias, conflict of interest (IESBA, 2013, p. 12). The auditor's objectivity is directly related to the ability to retain the client into the future (DeAngelo, 1981, pp. 113-127). The frequency of objectivity violations functions as an indicator of the level of independence (Fatemi, 2012, pp. 75-94).

\subsection{Professional Competence and Due Care}

This is about gaining and preserving appropriate technical and other pertinent skills and competence to execute the work, doing it completely and correctly, on a timely basis, and ensuring that users of the output are perceiving its context and limitations (CIPFA, p. 5).

$I t$; forces the following obligations on members: (a) to preserve professional knowledge and skill at the level wanted to ensure that clients or employers receive competent professional service (AAT- Code of Professional Ethics, 2014, p. 9), and (b) to act industriously in accordance with usable technical and professional standards when providing Professional Services (APES 110 - Code of Ethics for Professional Accountants, December 2010, p. 19).

\subsection{Confidentiality}

It is; to respect the confidentiality of information gained as an outcome of professional and business relationships (CIMA, 2015, p. 9). Furthermore, the principle of confidentiality should not impact the commitments of the persons concerned to supply information under criminal law (Official Journal of the European Union, L 348/75, 2010).

Although the auditor's professional obligation to maintain the exclusiveness of client information may prohibit such reporting, the auditor's legitimate responsibilities may exceed the duty of confidentiality in some circumstances (Professional Skepticism in an Audit of Financial Statements, no date).

\subsection{Professional Behavior}

It is; to obedience with relevant laws and regulations and avert any action that discredits the profession (CIMA, 2015 , p. 9). It; can also be characterized as "behavioral professionalism" - behaving in a way to achieve optimal outcomes in professional functions and interactions (Hammer, 2000, p. 456).

Also it; can be defined as the convenience of somebody's action or reaction either purposely or unintentionally towards the modifications of the environment or condition or situation that reflect on qualities that are attached to his or her responsibilities (Yusoff, 2009, pp. 1-2).

\subsection{Main Hypothesis}

There is no statistical significant relationship between the assimilation level of fundamental principles to achieve independence in the audit process; and Awareness Level Of Professional Independence Requirements (ALOPIR).

\subsection{Sub Hypotheses}

There is no statistical significant relationship between the...

1) integrity terms availability; and (ALOPIR)

2) objectivity items presence; and (ALOPIR)

3) professional competence and due care procedures application; and (ALOPIR)

4) professional behavior achievement; and (ALOPIR)

5) confidentiality obligations completion; and (ALOPIR)

6) safeguards performance; and (ALOPIR) 
7) threats identifying possibility; and (ALOPIR). (See Figure 1).

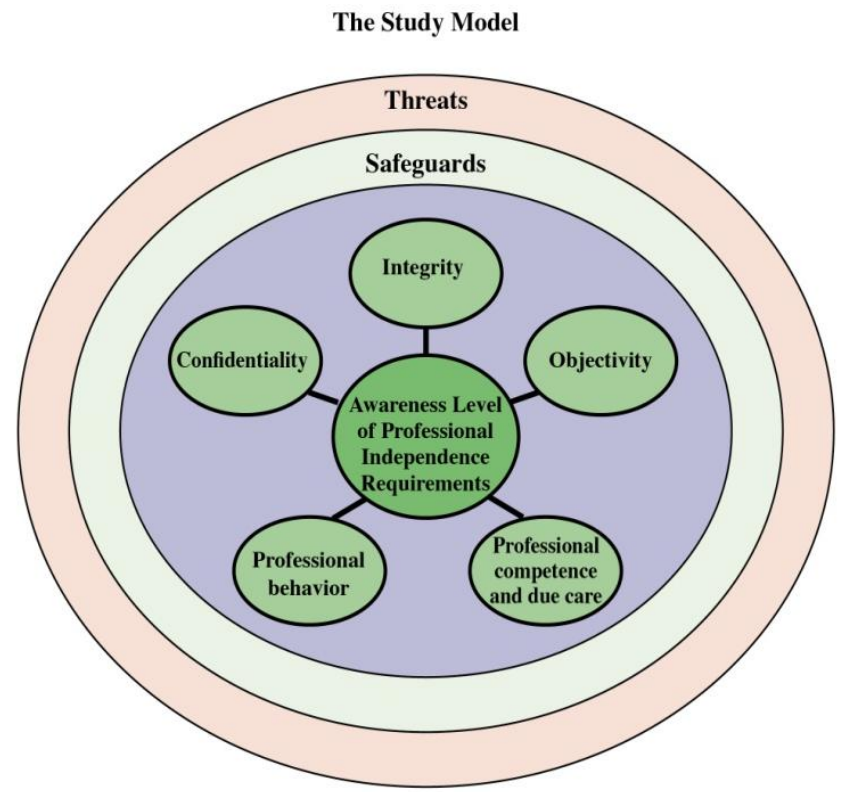

Figure 1 . The study model

\section{The Field Study}

\subsection{Materials and Methods}

Analytical process was used in this study based on the proportional data to realize the statistical analysis; such data was gathered by a questionnaire, which was prepared according to the essence of the study problem (See Tables: Q1 to Q8).

Table Q1. ALOPIR

\begin{tabular}{|c|c|c|c|c|}
\hline Num. & (01) Awareness Level of Professional Independence Requirements & Mean & $\%$ & St. D \\
\hline 1 & $\begin{array}{l}\text { 0.1- The auditor independence of mind appears in his ability to express his work results, without } \\
\text { responding to any external effects that may destroy his professional judgment. }\end{array}$ & 4.10 & 0.820 & 0.810 \\
\hline 2 & $\begin{array}{l}\text { 0.2- The independence of mind of professional accountant enables him to work efficiently and } \\
\text { effectively with integrity, to practice objectivity and skepticism. }\end{array}$ & 4.30 & 0.860 & 0.648 \\
\hline 3 & $\begin{array}{l}\text { 0. 3- The professional accountant independence in appearance results in a state of avoiding a group of } \\
\text { explicit situations and conditions before others, which may give reasons to doubt his neutrality and } \\
\text { objectivity. }\end{array}$ & 4.10 & 0.820 & 0.744 \\
\hline 4 & $\begin{array}{l}\text { 0.4- The professional accountant uses the conceptual framework of professional independence issued by } \\
\text { IFAC to determine the importance of threats against the independence, and to activate security } \\
\text { tools to reduce threats or to eliminate them. }\end{array}$ & 3.95 & 0.790 & 0.876 \\
\hline 5 & $\begin{array}{l}\text { 0.5-The professional accountant applies the Jordanian conceptual framework of professional } \\
\text { independence to specify and to evaluate threats and their importance to reduce or eliminate them. }\end{array}$ & 4.00 & 0.800 & 0.877 \\
\hline 6 & $\begin{array}{l}\text { 0.6- The professional accountant uses both quantity and quality factors in evaluating process of the } \\
\text { threats significance against professional independence. }\end{array}$ & 3.65 & 0.730 & 0.736 \\
\hline 7 & $\begin{array}{l}\text { 0.7- The professional accountant either eliminates or reduces all conditions and relations that cause } \\
\text { threats, or ends the audit agreement. }\end{array}$ & 3.98 & 0.796 & 0.920 \\
\hline 8 & $\begin{array}{l}\text { 0.8- The professional accountant establishes policies and procedures designed to ensure reasonable } \\
\text { assurance to preserve professional independence according to (ISQCs). }\end{array}$ & 3.83 & 0.766 & 0.781 \\
\hline 9 & $\begin{array}{l}\text { 0.9- The Professional accountant deduces certain result about the obedience to independence } \\
\text { requirements in the audit agreement, according to (ISAs). }\end{array}$ & 3.93 & 0.786 & 0.888 \\
\hline 10 & $\begin{array}{l}\text { 0.10- The professional accountant registers the results of obedience to the professional independence } \\
\text { requirements, besides the contents of relevant discussions which support these results. }\end{array}$ & 4.00 & 0.800 & 0.847 \\
\hline
\end{tabular}


0.11- The professional accountant is allowed to make adjustments to professional independence

11 requirements in special and certain cases, either when charging to audit special objects, or the $\begin{array}{lll}3.53 & 0.706 & 0.784\end{array}$ existence of limitations on using and notifying the report.

0.12- The auditing firm negotiates the independence requirements that must be applied, the threats against it and relative safeguards with the contractors, in harmony with engagement contract.

0.13- The professional independence requirements forbid the audit firm and team to merge in certain relations with clients capable to influence strongly the assurance information.

0.14- The audit firm evaluates the violation significance against professional independence requirements, and its effect on here objectivity and ability to release audit report, in accordance to international audit standards.

0.15 - The audit firm takes all necessary procedures in the case of violation against independence requirements, following the violation significance.

0.16- In case of violation existence to independence requirements, the audit firm either finishes the audit process, and the negative results, or informs the third party about the violation, or concludes its inability to release an audit report.

Table Q2. ITA

\begin{tabular}{|c|c|c|c|c|}
\hline Num. & (1)- Integrity Terms Availability & Mean & $\%$ & St. D \\
\hline 17 & $\begin{array}{l}\text { 1.1- Ethically, the professional accountant commits himself to be straightforward and honest in all of } \\
\text { his professional engagements. }\end{array}$ & 4.05 & 0.810 & 0.904 \\
\hline 18 & 1.2- The professional accountant behaves fairly in all of his professional engagements and dealings. & 3.83 & 0.766 & 1.059 \\
\hline 19 & $\begin{array}{l}\text { 1.3- Consciously, the professional accountant avoids either any significant misleading or fake } \\
\text { information, or prepared hurriedly by imprudent way. }\end{array}$ & 3.90 & 0.780 & 0.928 \\
\hline 20 & $\begin{array}{l}\text { 1.4- The professional accountant is considered to not be either violating or penetrating the integrity } \\
\text { principle, if he introduces modified report in the case of certain either passing or deviating of } \\
\text { the client data and information. }\end{array}$ & 3.43 & 0.686 & 0.931 \\
\hline \multicolumn{2}{|c|}{ The Variable Mean } & & 3.80 & \\
\hline
\end{tabular}

Table Q3. OIP

\begin{tabular}{ccccc}
\hline Num. & (2)- Objectivity Items Presence & Mean & \% & St. D \\
\hline 21 & $\begin{array}{l}\text { 2.1- The professional accountant obligates himself not to expose his objectivity to case of } \\
\text { bargaining and compromise, as a result of bias and conflict of interests }\end{array}$ & 3.90 & 0.780 & 0.841 \\
22 & $\begin{array}{l}\text { 2.2-The professional accountant protects his objectivity from exaggerate influence of others, and } \\
\text { avoids all circumstances and cases which may weaken it. }\end{array}$ & 3.90 & 0.780 & 0.910 \\
23 & $\begin{array}{l}\text { 2.3- The professional accountant educates himself and stud studys all cases and conditions that may } \\
\text { negatively influence his objectivity. }\end{array}$ & 3.80 & 0.760 & 0.687 \\
24 & $\begin{array}{l}\text { 2.4- The professional accountant introduces skilled service that not connected to bias conditions or } \\
\text { relations. }\end{array}$ & 3.80 & 0.760 & 0.758 \\
The Variable Mean & & 3.85 & \\
\hline
\end{tabular}

\section{Table Q4. PC\&DCA}

\begin{tabular}{|c|c|c|c|c|}
\hline Num. & (3)- Professional Competence and Due Care Application & Mean & $\%$ & St. D \\
\hline 25 & $\begin{array}{l}\text { 3.1- The professional accountant preserves and develops excellent knowledge and skills with } \\
\text { high levels, to ensure the client who uses the introduced professional service. }\end{array}$ & 4.03 & 0.806 & 0.891 \\
\hline 26 & $\begin{array}{l}\text { 3.2- The professional accountant practices his judgment in a sound way, at the introduction } \\
\text { of the skillful service. }\end{array}$ & 4.00 & 0.800 & 0.906 \\
\hline 27 & $\begin{array}{l}\text { 3.3- The professional accountant obligates himself with necessary due care, according to the } \\
\text { task requirements, at the correct time. }\end{array}$ & 3.90 & 0.780 & 0.744 \\
\hline 28 & $\begin{array}{l}\text { 3.4- The professional accountant takes steps to be insured that his employees have relative } \\
\text { training and supervising. }\end{array}$ & 3.85 & 0.770 & 0.770 \\
\hline 29 & $\begin{array}{l}\text { 3.5- The professional accountant works to make his clients, employees and workers aware of } \\
\text { limits and determinants accompanying service introduction. }\end{array}$ & 3.85 & 0.770 & 0.736 \\
\hline \multicolumn{2}{|c|}{ The Variable Mean } & & 3.93 & \\
\hline
\end{tabular}


Table Q5. PBA

\begin{tabular}{|c|c|c|c|c|}
\hline Num. & (4)- Professional Behavior Achievement & Mean & $\%$ & St. D \\
\hline 30 & $\begin{array}{l}\text { 4.1- The professional accountant obligates himself with professional behavior, in obeying to } \\
\text { laws and lists relating to the profession, and avoids any action that may disgrace his } \\
\text { professional reputation. }\end{array}$ & 4.30 & 0.860 & 0.758 \\
\hline 31 & $\begin{array}{l}\text { 4.2-The professional accountant avoids disgracing his professional reputation, when } \\
\text { marketing and publicizing himself and his job. }\end{array}$ & 4.13 & 0.826 & 0.822 \\
\hline 32 & $\begin{array}{l}\text { 4.3- The professional accountant abides himself with truth, honest and not exaggerating, } \\
\text { concerning the marketing of his services or qualifications, or experiences, or the } \\
\text { overstating his fees. }\end{array}$ & 4.10 & 0.820 & 0.744 \\
\hline 33 & $\begin{array}{l}\text { 4.4- The professional accountant avoids making any harmful signals to his colleagues work, or } \\
\text { doing not documented comparisons with other works. }\end{array}$ & 3.93 & 0.786 & 0.764 \\
\hline \multicolumn{2}{|c|}{ The Variable Mean } & & 4.11 & \\
\hline
\end{tabular}

Table Q6. COC

\begin{tabular}{|c|c|c|c|c|}
\hline Num. & (5)- Confidentiality Obligations Completion & Mean & $\%$ & St. D \\
\hline 34 & $\begin{array}{l}\text { 5.1-Without the existence either of certain authority or relevant empowerment; the } \\
\text { professional accountant abstains himself from releasing information of the audited } \\
\text { company, which he acquired through work relations. }\end{array}$ & 4.15 & 0.830 & 0.770 \\
\hline 35 & $\begin{array}{l}\text { 5.2- The professional accountant obligates himself not to use special information either for } \\
\text { self utilization, or for third party benefit. }\end{array}$ & 3.93 & 0.786 & 1.023 \\
\hline 36 & $\begin{array}{l}\text { 5.3- The professional accountant preserves confidentiality within the social environment, and } \\
\text { takes care from not deliberate leaks of information, either for relatives or other parties. }\end{array}$ & 3.98 & 0.796 & 1.000 \\
\hline 37 & $\begin{array}{l}\text { 5.4- The professional accountant takes steps to ensure that his employees, assistants and } \\
\text { advisors respect the "confidentiality concept". }\end{array}$ & 4.20 & 0.840 & 0.853 \\
\hline 38 & $\begin{array}{l}\text { 5.5- The "confidentiality concept" is obligated even after the ending of the work relation } \\
\text { between the professional accountant and the client. }\end{array}$ & 4.03 & 0.806 & 1.025 \\
\hline 39 & $\begin{array}{l}\text { 5.6- The professional accountant discovers private information, if it is legally permitted, and } \\
\text { by the client approval with relative delegation. }\end{array}$ & 4.13 & 0.826 & 0.939 \\
\hline 40 & $\begin{array}{l}\text { 5.7- The professional accountant discovers secret information, if the uncovering is needed as } \\
\text { evidence for judicial disputes, or in the case of juridical infraction. }\end{array}$ & 4.00 & 0.800 & 0.934 \\
\hline 41 & $\begin{array}{l}\text { 5.8- The professional accountant discovers secret information, if uncovering is professional } \\
\text { requirement, in the case of quality control and the counterpart review. }\end{array}$ & 3.88 & 0.776 & 0.822 \\
\hline 42 & $\begin{array}{l}\text { 5.9- When making a decision to either cover or uncover special information, the professional } \\
\text { accountant takes in account, the sort of the probable contact and to whom the contacting } \\
\text { will be done, }\end{array}$ & 4.00 & 0.800 & 0.906 \\
\hline \multicolumn{2}{|c|}{ The Variable Mean } & & 4.03 & \\
\hline
\end{tabular}

Table Q7. SP

\begin{tabular}{|c|c|c|c|c|}
\hline Num. & (6)-Safeguards Performance & Mean & $\%$ & St. D \\
\hline 43 & $\begin{array}{l}\text { 6.1- The professional accountant has suitable qualification of experience, training and } \\
\text { education that enable him to practice his job and to avoid threats. }\end{array}$ & 3.83 & 0.766 & 0.931 \\
\hline 44 & $\begin{array}{l}\text { 6.2- The professional accountant constantly tries to acquire the continual professional } \\
\text { developing requirements. }\end{array}$ & 3.90 & 0.780 & 0.744 \\
\hline 45 & $\begin{array}{l}\text { 6.3- The professional accountant understands fully and implements the firm organizational } \\
\text { lists, procedures and governance contents. }\end{array}$ & 3.70 & 0.740 & 1.067 \\
\hline 46 & $\begin{array}{l}\text { 6.4- The professional accountant has deep informing and understanding to the local and } \\
\text { international standards necessary to do his job efficiently and effectively. }\end{array}$ & 3.68 & 0.736 & 1.071 \\
\hline 47 & $\begin{array}{l}\text { 6.5- The professional accountant executes the organizational procedures, the control and } \\
\text { professional system in his work aspect. }\end{array}$ & 3.78 & 0.756 & 1.074 \\
\hline 48 & $\begin{array}{l}\text { 6.6- The professional accountant uses the external audit of third legally qualified party, to } \\
\text { quality verification system of the achieved work, in the audit firm. }\end{array}$ & 3.10 & 0.620 & 1.150 \\
\hline \multicolumn{3}{|c|}{ The Variable Mean } & 3.66 & \\
\hline
\end{tabular}


Table Q8. TIP

\begin{tabular}{|c|c|c|c|c|}
\hline Num. & (7)- Threats Identifying Possibility & Mean & $\%$ & St. D \\
\hline 49 & $\begin{array}{l}\text { 7.1- The professional accountant avoids the personal benefit threat, which may negatively } \\
\text { affect his professional judgment and behavior, if the threat exists. }\end{array}$ & 3.88 & 0.776 & 0.686 \\
\hline 50 & $\begin{array}{l}\text { 7.2- The professional accountant fully realizes personal audit threat, which means } \\
\text { reevaluating the results of previous work achieved by him. }\end{array}$ & 3.80 & 0.760 & 0.687 \\
\hline 51 & $\begin{array}{l}\text { 7.3- The professional accountant deeply understands the threat of supporting the others job, } \\
\text { which may demolish his professional objectivity. }\end{array}$ & 3.70 & 0.740 & 0.723 \\
\hline 52 & $\begin{array}{l}\text { 7.4 Relatively the professional accountant realizes the threat of familiarity and habituation, } \\
\text { and works diligently either to neutralize, or to demolish it. }\end{array}$ & 3.85 & 0.770 & 0.834 \\
\hline 53 & $\begin{array}{l}\text { 7.5- Excellently the professional accountant fortifies himself against threat of frightening and } \\
\text { annoying, through resistance to actual and realized pressures. }\end{array}$ & 3.83 & 0.766 & 0.747 \\
\hline \multicolumn{2}{|c|}{ The Variable Mean } & & 3.81 & \\
\hline
\end{tabular}

The researchers used the correlation test to measure the awareness level of professional independence requirements, through assimilation of fundamental principles of professional ethics, by Jordanian CPA auditors, in auditing process. As the strength of the correlation factor; points to the awareness level of Jordanian CPA auditors concerning the professional independence requirements. (See Table 3).

In addition to extracting the arithmetic means of the questionnaire fields and paragraphs to compare with the standardized mean; to accept or reject the stated hypotheses, to achieve the previous goal. (See Table 5).

\subsection{Study Limits}

This study was conducted on auditing firms and CPA auditors operating in Jordan, but we must keep in mind the fact that there are international and local auditing and accounting codes and standards to be followed by them, so we focused our search to identify the extent to which awareness level of professional independence requirements - of Jordanian CPA auditors - has reached, the matter which may be reflected in the quality level of their work outputs.

\subsection{Population and Study Sample}

The study population - (501) authorized person and firm - consists of the auditing firms and CPA auditors operating in Jordan, the ultimate designed questionnaire was delivered by hand to the sample of the study, a number of questionnaires was distributed, (40) questionnaires were suitable for analysis. Thus, the percentage of valid questionnaires and recovered for analysis is nearly about (0.08).

\section{Statistical Used Methods}

The (Statistical Package for Social Sciences-SPSS) was used to analyze the questionnaire outputs, so as to accept or reject the pointed hypotheses. by the significant level (5\%), which is accepted in the social sciences in general, and supplements the confidence level of $(95 \%)$.

\subsection{Cronbach's Alpha}

To explore the study tool with its credibility in testing hypotheses, and to realize the objectives of the study, internal uniformity scale Cronbach's Alpha was used to gauge the truthfulness of the study sample answers. According to (Sekaran, 2003); the internal consistency coefficient between the answers, that is a statistically acceptable value for this scale is $(60 \%)$ or more.

It is noted that the total (Cronbach's Alpha) value of the (53) questions was (0.973), and the results of calculating this value of each variable show that the consistency was very high, the matter which emphasizes the reliability of the questionnaire to test hypotheses, as clarified in the Table 1. So; there is a strong possibility to rely on the analysis results of the study tool.

Table 1. Reliability statistics

\begin{tabular}{lcc}
\hline & Cronbach's Alpha & N of Items \\
\hline $\mathbf{5 3}$ Questions & .973 & 53 \\
Awareness Level of Professional Independence Requirements & .908 & 16 \\
Integrity terms availability & .801 & 4 \\
Objectivity items presence & .839 & 4 \\
\hline
\end{tabular}




\begin{tabular}{lcc}
\hline & Cronbach's Alpha & N of Items \\
\hline Professional Competence and Due Care procedures application & .910 & 5 \\
Professional Behavior achievement & .859 & 4 \\
Confidentiality obligations completion & .961 & 9 \\
Safeguards performance & .928 & 6 \\
Threats identifying possibility & .808 & 5 \\
\hline
\end{tabular}

\subsection{One-Sample Kolmogrove-Smirnove Test, $K$-S}

This test was done to know the distribution nature of answers to each variable questions, the decision basis will be as follows:

Ho: If (Asymp.Sig. (2-tailed), $K$-S) is $\geq 5 \%$ : the distribution is normal.

H1: If (Asymp.Sig. (2-tailed), $K-S$ ) is $<5 \%$ : the distribution is not normal.

From Table 2 we can see that (Asymp. Sig. (2-tailed)) of each variable is above the stated percentage 5\%, so; the alternative hypothesis will be accepted, and the answers to the questionnaire questions a normally distributed, the matter which means the possibility to achieve relative analysis, and to reach reasonable results.

Table 2. One-sample kolmogorov-smirnov test

\begin{tabular}{|c|c|c|c|c|c|c|c|c|c|}
\hline & & ALOPIR & ITA & OIP & PC\&DCA & PBA & $\mathrm{COC}$ & SP & TIP \\
\hline \multicolumn{2}{|l|}{$\mathrm{N}$} & 40 & 40 & 40 & 40 & 40 & 40 & 40 & 40 \\
\hline \multirow{2}{*}{$\begin{array}{l}\text { Normal } \\
\text { Parameters }{ }^{\mathrm{a}, \mathrm{b}}\end{array}$} & Mean & 3.82 & 3.80 & 3.85 & 3.93 & 4.11 & 4.03 & 3.66 & 3.81 \\
\hline & Std. Deviation & .544 & .758 & .638 & .697 & .648 & .805 & .871 & .555 \\
\hline \multirow{3}{*}{$\begin{array}{l}\text { Most Extreme } \\
\text { Differences }\end{array}$} & Absolute & .108 & .179 & .143 & .143 & .162 & .160 & .178 & .143 \\
\hline & Positive & .104 & .082 & .109 & .099 & .144 & .125 & .099 & .116 \\
\hline & Negative & -.108 & -.179 & -.143 & -.143 & -.162 & -.160 & -.178 & -.143 \\
\hline \multicolumn{2}{|c|}{ Kolmogorov-Smirnov Z } & .683 & 1.133 & .904 & .904 & 1.027 & 1.011 & 1.124 & .903 \\
\hline \multicolumn{2}{|c|}{ Asymp. Sig. (2-tailed) } & .739 & .154 & .387 & .388 & .242 & .258 & .160 & .388 \\
\hline
\end{tabular}

a. Test distribution is Normal; b. Calculated from data.

ALOPIR: Awareness Level of Professional Independence Requirements; ITA: Integrity Terms Availability; OIP: Objectivity Items Presence; $\boldsymbol{P C} \& \boldsymbol{D C A}$ : Professional Competence and Due Care Application; PBA: Professional Behavior Achievement; $\boldsymbol{C O C}$ : Confidentiality Obligations Completion; SP: Safeguards Performance; TIP: Threats Identifying Possibility.

\subsection{Correlations Test}

This test was done to state the extent of awareness level of professional independence requirements, through assimilation of fundamental principles of professional ethics, by Jordanian CPA auditors, in auditing process, as this level is a reasonable reflection of the correlation value strength. As the CPA auditor realization, understanding, conception and awareness of the variable paragraphs and questions content, enables him to judge relatively the invisible connections between each question and others. To determine which hypothesis to be chosen; the decision basis will be as follows:

Ho: If (Sig. (2-tailed) is $>5 \%$, the null hypothesis will be accepted.

H1: If (Sig. (2-tailed) is $\leq 5 \%$, the alternative hypothesis will be accepted.

From Table 3 we can see that (Sig. (2-tailed) of all variables is < 5\%, so: the alternative hypothesis of each variable will be accepted. This proves that there is a statistically significant relationship between each of the integrity terms availability; objectivity items presence; professional competence and due care procedures application; professional behavior achievement; confidentiality obligations completion; safeguards performance and threats identifying possibility; and (ALOPIR) 
Table 3. Correlations

\begin{tabular}{clcccccccc}
\hline & ALOPIR & ITA & OIP & PC\&DCA & PBA & COC & SP & TIP \\
\hline \multirow{3}{*}{ ALOPIR } & Pearson Correlation & 1 & $.353^{*}$ & $.654^{* *}$ & $.753^{* *}$ & $.778^{* *}$ & $.519^{* *}$ & $.720^{* *}$ & $.773^{* *}$ \\
& Sig. (2-tailed) & & $\mathbf{. 0 2 5}$ & $\mathbf{. 0 0 0}$ & $\mathbf{. 0 0 0}$ & $\mathbf{. 0 0 0}$ & $\mathbf{. 0 0 1}$ & $\mathbf{. 0 0 0}$ & $\mathbf{. 0 0 0}$ \\
& $\mathrm{N}$ & 40 & 40 & 40 & 40 & 40 & 40 & 40 & 40 \\
\hline
\end{tabular}

*. Correlation is significant at the 0.05 level (2-tailed); **. Correlation is significant at the 0.01 level (2-tailed).

ALOPIR: Awareness Level of Professional Independence Requirements; ITA: Integrity Terms Availability; OIP: Objectivity Items Presence; PC\&DCA: Professional Competence and Due Care Application; PBA: Professional Behavior Achievement; COC: Confidentiality Obligations Completion; $\boldsymbol{S P}$ : Safeguards Performance; TIP: Threats Identifying Possibility.

\subsection{Rule of Thumb}

The Pearson Correlation values in Table 3 indicate to the awareness of professional independence requirements, through assimilation of fundamental principles of professional ethics, by Jordanian CPA auditors, in auditing process.

So, by following the rule of thumb for interpreting the size of a correlation coefficient, that is stated in table (4) and by using the Pearson Correlation values from Table 3 we can sort the value of Pearson correlation between (ALOPIR) variable; and each of the other variables as follows:

- High Positive Correlation with each of professional competence and due care procedures application, professional behavior achievement, safeguards performance and threats identifying possibility;

- Moderate Positive Correlation with each of objectivity items presence and $\underline{\text { confidentiality }}$ obligations completion;

- Low positive correlation with integrity terms availability.

Table 4. Rule of thumb for interpreting the size of a correlation coefficient

\begin{tabular}{ll}
\hline Size of Correlation & Interpretation \\
\hline .90 to $1.00(-.90$ to -1.00 & Very high positive (negative) correlation \\
.70 to $.90(-.70$ to -.90$)$ & High positive (negative) correlation \\
.50 to $.70(-.50$ to -.70$)$ & Moderate positive (negative) correlation \\
.30 to $.50(-.30$ to -.50$)$ & Low positive (negative) correlation \\
.00 to $.30(.00$ to -30$)$ & Negligible correlation \\
\hline
\end{tabular}

*Hinkle DE, Wiersma W, Jurs SG (2003) Applied Statistics for the Behavioral Sciences $5^{\text {th }}$ ed. Boston: Houghton Mifflin.

This result may indicates to the lack of professional auditing culture, that explains with depth the substance of professional ethics which may differ in the practical environment than the social moral, that may considers the cooperate with relatives - for example - as a moral action.

\subsection{Standardized Mean Test}

Through this test, we will calculate the means of each hypothesis as follows:

1) The standardized mean of each question is as follows: $(1+2+3+4+5) / 5=\{(\underline{\mathbf{3}})\}$ this is to be compared with.

2) The hypothesis mean $=$ the mean of "awareness level of professional independence requirements" variable + the mean of each other variable) / 2

The decision basis will be as follows:

Ho: accept the null hypothesis if the joint mean average is < (3).

H1: accept the alternative hypothesis if the joint mean average is $\geq(3)$. 
Table 5. Joint mean average

\begin{tabular}{lcccccccc}
\hline & ALOPIR & ITA & OIP & PC\&DCA & PBA & COC & SP & TIP \\
\hline Variable Mean & 3.82 & 3.80 & 3.85 & 3.93 & 4.11 & 4.03 & 3.66 & 3.81 \\
ALOPIR & JMA & 3.81 & 3.84 & 3.88 & 3.97 & 3.93 & 3.74 & 3.82 \\
\hline
\end{tabular}

JMA: Joint Mean Average; ALOPIR: Awareness Level of Professional Independence Requirements; ITA: Integrity Terms Availability; OIP: Objectivity Items Presence; $P C \& D C A$ : Professional Competence and Due Care Application; $P B A$ : Professional Behavior Achievement; $C O C$ : Confidentiality Obligations Completion; SP: Safeguards Performance; TIP: Threats Identifying Possibility.

From Table 5 we can notice that the joint mean average - of each hypothesis - is more than the standardized mean (3), so the alternative one of each hypothesis will be accepted.

Also; from Table 5 we can sort the hypotheses according to the size of joint mean as follows:

1) (H4)- There is a statistically significant relationship between the professional behavior achievement; and (ALOPIR)

2) (H5)- There is a statistically significant relationship between the confidentiality obligations completion; and (ALOPIR)

3) (H3)- There is a statistically significant relationship between the professional competence and due care procedures application; and (ALOPIR)

4) (H2)- There is a statistically significant relationship between the objectivity items presence; and (ALOPIR)

5) (H7)- There is a statistically significant relationship between the threats identifying possibility; and (ALOPIR)

6) (H1)- There is a statistically significant relationship between the integrity terms availability; and (ALOPIR)

7) (H6)- There is a statistically significant relationship between the safeguards performance; and (ALOPIR)

This indicates the ranks of assimilation the fundamental principles of professional ethics by Jordanian CPA auditors, in their audit processes, the matter that reflects in the awareness level of the professional independence requirements.

The researchers would like to draw the attention to the last three ranks, in the $5^{\text {th }}$ rank lays the threats identifying possibility variable, then the integrity terms availability variable in the $6^{\text {th }}$ rank, after that in the $7^{\text {th }}$ rank comes the safeguards performance variable.

Such thing is in contradiction with the logical assumptions of this study, as the integrity terms availability variable must be at the $1^{\text {st }}$ rank, the safeguards performance variable must be at the $6^{\text {th }}$ rank, and the threats identifying possibility variable must be in the $7^{\text {th }}$ rank. This may indicate to the nature of the prevailing social environment in the area, whereas the dominant threats percentages rise to very high levels, so; the individual may be compelled to focus his attention on how to identify such threats, and therefore to give them priority over the commitment to integrity, which might be regarded to be through solidarity with relatives, more than to be as ethical type that must be reflected in the professional work techniques. As a result, this may reduce the interest to take necessary preventive means, precautions and safeguards, by pushing them to be at the bottom line of the concerns list.

\section{Conclusions}

After the execution of the statistical analysis which included:

- first; the extraction of the internal matchmaking scale Cronbach's Alpha, that was used to measure the truthfulness of the study sample answers,

- $\quad$ second; the One-Sample Kolmogrove-Smirnove Test, K-S, that was done to know the distribution nature of answers to each variable questions,

- third; the Correlations Test that was done to discover the power of the connections values between the study variables,

- fourth; following the Rule of Thumb for interpreting the size of a correlation coefficient,

- $\quad$ fifth; the Standardized Mean Test to extract the means of each question, each variable and each hypothesis, to compare with the stated standardized mean, according to likert Scale, depending on decision basis to accept or reject the null or alternative hypotheses. 
The results were as follows, According to:

- Cronbach's Alpha: the internal consistency of the total questions and each variable was above the separator limit 60\%.

- One-Sample Kolmogrove-Smirnove Test, K-S: the (Asymp. Sig. (2-tailed)) of each variable was above the stated percentage level 5\%, and all answers to the questions were normally distributed.

- Correlations Test: the (Sig. (2-tailed)) of each variable was less than 5\% so: the alternative hypothesis of each variable was accepted.

- Rule of Thumb: for interpreting the size of a correlation coefficient; which stated that each variable was either moderate or strong, except one variable which was considered to be weak.

- Standardized Mean Test: all hypotheses' joint means were above the standardized mean, so; every alternative hypothesis of the study was accepted.

As in the awareness of professional independence requirements; integrity must be the cornerstone of the auditor mind, and serious percussions must be taken in advance to build a solid protection wall against threats, which may endanger his independence and job if the case they take place occured.

\section{Recommendations}

As the world with all of its components is an evolving one, with rapid and complicated movements, and as every person is in need to follow up through relevant convoy with these changes by acquiring suitable learning and good practical experiences, in his job or work, the same is the professional accountant or auditor, especially in the subjects that affect his material work; the moral side and ethics. So, steps must be taken to achieve:

- Imminent, deep and effectively spreading of relative culture to them - especially the fundamental principles of professional ethics - among professional accountants

- Much effort must be exerted to release a formal profession and ethics Charter of audit in Jordan, what is available at present is just an informal draft

- Inserting a special course concerning the profession of auditing in accounting departments of business colleges in Jordanian universities

\section{References}

AAT-Code of Professional Ethics. (2014). Retrieved from https://www.aat.org.uk/sites/default/files/assets/AAT_Code_of_Professional_Ethics.pdf

AICPA. (2001). AICPA - Professional Ethics Executive Committee, White Paper, Independence Rules Modernization Project. Retrieved from https://www.aicpa.org/InterestAreas/ProfessionalEthics/Resources/Tools/DownloadableDocuments/Indepen denceModernizationWhitePaper.doc

APB. (2009). APB - Ethical Standard 3 (Revised) Long Association With The Audit Engagement. Retrieved from https://frc.org.uk/Our-Work/Publications/APB/ES-3-(Revised)-Long-Association-with-the-Audit-Eng.aspx

APES. (2010). APES 110 - Code of Ethics for Professional Accountants, December 2010. Retrieved from http://www.apesb.org.au/uploads/standards/apesb_standards/standard1.pdf

Arens, A., Elder, R., \& Beasly, M. (2006). Auditing and Assurance Services: An Integrated Approach (11th ed.). Prentice-Hall, Englewood Cliffs, NJ. from http://www.abebooks.com/Auditing-Assurance-Services-Integrated-Approach-11th/4321857199/bd

Arya, A., \& Jonathan, G. (2014). Auditor Independence Revisited. Journal of Accounting, Auditing \& Finance, 29(2), 188-198. http://dx.doi.org/10.1177/0148558X13519989

Barabás, T. (2013). On the Independence of Auditors, with Special Regard to the Financial Sector. Public Finance Quarterly (0031-496X). State Audit Office of Hungary. Retrieved from https://ideas.repec.org/a/pfq/journl/v58y2013i2p184-198.html

Barrett, M., Cooper, D. J., \& Jamal, K. (2005). Globalization and the coordinating of work in multinational audits. Accounting, Organizations and Society, 30(1), 1-24. http://dx.doi.org/10.1016/j.aos.2004.02.002

Blann, S. W. (2010). Auditor Independence in the Public Sector. Government Finance Review, 26(4), 40-44. Retrieved from https://www.questia.com/magazine/1G1-235857301/

Blay, A. D. (2005). Independence threats, litigation risk, and the auditor's decision process. Contemporary 
$\begin{array}{llll}\text { Accounting } & \text { Research, } & \text { 22(Winter), } & \text { 759-789. }\end{array}$ http://dx.doi.org/10.1506/5FQ9-ANEA-T8J0-U6GY

CIMA - Charted Institute of Management Accountants. (2015). CIMA Code Of Ethics For Professional Accountants.

Retrieved

from http://www.cimaglobal.com/Professional-ethics/Ethics/CIMA-code-of-ethics-for-professional-accountants/

CIPFA, the Chartered Institute of Public Finance and Accountancy. (2011). Ethics and You: A Guide to the CIPFA Standard of Professional Practice on Ethics. Retrieved from http://www.cipfa.org.uk/conduct/ethics.cfm

DeAngelo, L. (1981). Auditor independence, "low balling," and disclosure regulation. Journal of Accounting and Economics, 3(2), 113-127. http://dx.doi.org/10.1016/0165-4101(81)90009-4

Dopuch, N., \& King, R. R. (1996). The effects of lowballing on audit quality: An experimental markets study. Journal of Accounting, Auditing, and Finance, 11(Winter), 45-68. http://dx.doi.org/10.1177/0148558X9601100102

Fatemi, D. J. (August 2012). An Experimental Investigation of the Influence of Audit Fee Structure and Auditor Selection Rights on Auditor Independence and Client Investment Decisions. Auditing: A Journal of Practice \& Theory, 31(3), 75-94. http://dx.doi.org/10.2308/ajpt-10289

Hammer, D. P. (Winter 2000). Professional Attitudes and Behaviors: The "A's and B's" of Professionalism. American Journal of Pharmaceutical Education, 64. Retrieved from http://www.aacp.org/resources/studentaffairspersonnel/studentaffairspolicies/documents/asandbsofprofessin alism.pdf

Hinkle, D. E., Wiersma, W., \& Jurs, S. G. (2003). Applied Statistics for the Behavioral Sciences (5th ed.). Boston: Houghton Mifflin. Retrieved from https://www.amazon.com/Applied-Statistics-Behavioral-Sciences-Dennis/dp/0618124055

Hung-Chao, Y. (2011). Legal systems and auditor independence. Rev Account Stud., 16, $377-411$. http://dx.doi.org/10.1007/s11142-011-9141-z

IESBA - International Ethics Standards, Board for Accountants. (2013). Handbook of the Code of Ethics for Professional Accountants, $2013 \quad$ Edition. Retrieved from https://www.ifac.org/publications-resources/2013-handbook-code-ethics-professional-accountants

IFAC. (n. d.). Professional Skepticism in an Audit of Financial Statements. Retrieved from http://www.ifac.org/sites/default/files/publications/files/IAASB\%20Professional\%20Skepticism\%20QandA -final.pdf

Karaja, A. A. M. (2004). The Obligation Range of External Accounts Auditors to Professional Behavior Rules in Jordan, and the Instruments to Courage them to Commit these Rules: Field Study. Ph.D Dissertation, Amman Arab University for High Studies. Retrieved from http://alqashi.com/wp/?page_id=796

Marshall, A., Geiger, D., Jordan, L., \& Kurt, P. (June 2, 1999). The Effects of Internal Audit Outsourcing on Perceived External Auditor Independence. http://dx.doi.org/ 10.2308/aud.1999.18.s-1.7

Muthui et al. (2014). Factors Affecting External Auditors' Independence In Discharging Their Responsibilities: A Survey Of Medium Level Auditing Firms In Nairobi. Int. J. Business \& Law Research, 2(4), 22-35.

Official Journal of the European Union, L 348/75. Retrieved from http://ec.europa.eu/health/files/eudralex/vol-1/dir_2010_84/dir_2010_84_en.pdf

Paterson, J. S., \& Adrian, V. (Winter 2011). The Effects of Recurring and Nonrecurring Tax, Audit-Related, and Other Non-audit Services on Auditor Independence. Contemporary Accounting Research, 28(5), 1510-1536. http://dx.doi.org/ 10.1111/j.1911-3846.2010.01060.x

Professional Independence and the ABCPF Member. (May 2000). RPF, Association of BC Professional Foresters, \#1201 - 1130 West Pender Street, Vancouver, BC V6E 4A4. Retrieved from http://www.abcfp.ca/regulating_the_profession/documents/guideline-independence.pdf

Ryan, S. G., Robert, H. H., ... Linda, V. (2001). Commentary: SEC Auditor Independence Requirements, AAA Financial Accounting Standards Committee. Accounting Horizons, 15, 373-386. http://dx.doi.org/10.2308/acch.2001.15.4.373

SEC - Securities And Exchange Commission. (2001). Final Rule: Revision of the Commission's Auditor 
Independence Requirements. Retrieved from https://www.sec.gov/rules/final/33-7919.htm

Sekaran, U. (2003). Research Method for Business: A Skill Building Approach (4th ed.). New York: John Wiley and Sons. Retrieved from https://www.scribd.com/doc/192282448/

The Auditing Practices Board. (n. d.). APB Ethical Standard 1 (Revised). Retrieved from https://www.frc.org.uk/Our-Work/Publications/APB/ES-1-(Revised)-Integrity,-objectivity-and-independ.pdf

The Commission Of The European Communities. (n. d.). Commission Recommendation, Statutory Auditors' Independence In The EU: A Set Of Fundamental Principles. Retrieved from http://www.iasplus.com/en/binary/resource/euaudit.pdf

Yusoff, M. S. B. (2009). Professional Behaviour: What Does It Means? Professional Behaviour: What Does it Means? Education in Medicine Journal, 1(1). http://dx.doi.org/10.5959/eimj.1.1.2009.c1

\section{Websites}

https://www.sec.gov/rules/final/33-7919.htm

http://citeseerx.ist.psu.edu/viewdoc/download?doi=10.1.1.309.5298\&rep=rep1\&type=pdf

http://ec.europa.eu/health/files/eudralex/vol-1/dir_2010_84/dir_2010_84_en.pdf

http://en.wikipedia.org/wiki/Awareness

http://eur-lex.europa.eu/LexUriServ/LexUriServ.do?uri1/4COM:2010:0561:FIN:EN:PDF

http://financial.kaplan.co.uk/Documents/ICAEW/codes_professional_ethics.pdf

http://link.springer.com/article/10.1007\%2Fs11142-011-9141-z\#page-1

http://pcaobus.org/rules/rulemaking/docket037/release_2011-006.pdf

http://www.abcfp.ca/regulating_the_profession/documents/guideline-independence.pdf

http://www.aicpa.org/_catalogs/masterpage/Search.aspx?S=independence+definitions

http://www.asz.hu/public-finance-quarterly-articles/2013/on-the-independence-of-auditors-with-special-regard-t o-the-financial-sector/a-184-198-Fatemit-2013-2.pdf

http://www.cpaaustralia.com.au/ /media/corporate/allfiles/document/professional-resources/auditing-assurance/g uide-understanding-audit-assurance.pdf

http://www.iasplus.com/en/binary/resource/euaudit.pdf

http://www.ifac.org/sites/default/files/publications/files/IAASB\%20Professional\%20Skepticism\%20QandA-final .pdf

http://www.merriam-webster.com/dictionary/awareness

https://books.google.co.uk/books?id=xDagK

https://facultystaff.richmond.edu/ mgeiger/.../AuditOutsourcing012799...

https://translate.google.com/\#en/ar/Aware

https://www.frc.org.uk/Our-Work/Publications/APB/ES-1-(Revised)-Integrity,-objectivity-and-independ.pdf https://www.frc.org.uk/Our-Work/Publications/APB/ES-3-(Revised)-Long-Association-with-the-Audit-Eng.pdf https://www.sec.gov/rules/final/33-7919.htm

http://www.rpf-bc.org

\section{Copyrights}

Copyright for this article is retained by the author(s), with first publication rights granted to the journal.

This is an open-access article distributed under the terms and conditions of the Creative Commons Attribution license (http://creativecommons.org/licenses/by/4.0/). 